\title{
Does decentralised governance of primary education improve performance of pupils in Eastern Uganda? - Perspectives of education managers
}

\section{Commonwealth Journal of Local Governance}

Issue 23: 2020

http://epress.lib.uts.edu.au/ojs/index.php/cjlg

\author{
Rose B Namara \\ Uganda Management Institute \\ PO Box 20131 \\ Kampala \\ Uganda \\ Email: rosenamara@gmail.com
}

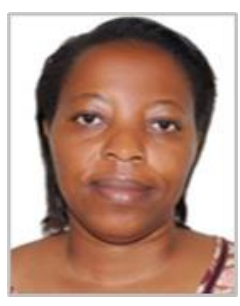

\begin{abstract}
This study seeks to establish the role decentralised governance has played in the performance of primary schools in eastern Uganda. Exploratory and descriptive data drawn from 104 school managers and district officials participating in the study indicate that decentralised governance has strengthened management of the payroll, increased regularity of monitoring and supervision and introduced school management committees. Despite these improvements in governance, there is however evidence that the quality of primary education continues to be low. Only a small and declining percentage of pupils complete primary education, and with increasingly poor grades. This is because, for a number of reasons, both the supply and demand side of governance are still weak. Despite this, overall the author finds that decentralised governance of primary education is a positive development, as it has enhanced the supply side of governance. There is, however, a need to control negative practices in the supply side of governance, and to systematically develop the demand side of governance, if the performance of Ugandan pupils is to improve.
\end{abstract}

Keywords: Primary education, decentralisation, governance, pupil performance, education managers

\section{Introduction}

Shortly after the introduction of the Universal Primary Education in 1997, the Government of Uganda decentralised governance of primary education through both supply side reforms (eg provision of restricted capitation and facility grants to schools, decentralising teacher recruitment and deployment to district levels, and decentralising school supervision) and demand side reforms (eg increased emphasis on citizen participation by the creation of school management committees (SMCs) to promote proper management and administration of schools). The aim was to eventually achieve better performance of pupils. However, the performance of pupils in Ugandan public schools as measured by proficiency in literacy and numeracy continues to be low with literacy for year six of primary (known

DOI: https://doi.org/10.5130/cjlg.vi23.7537

Article History: Received 19/07/18; Accepted 17/11/20; Published 16/12/20

Citation: Commonwealth Journal of Local Governance 2020, 23: 7537, https://doi.org/10.5130/cjlg.vi23.7537

(C) 2020 Rose B Namara. This is an Open Access article distributed under the terms of the Creative Commons Attribution 4.0 Unported (CC BY 4.0) License (https://creativecommons.org/licenses/by/4.0/), allowing third parties to copy and redistribute the material in any medium or format and to remix, transform, and build upon the material for any purpose, even commercially, provided the original work is properly cited and states its license. 
as 'Primary 6') standing at $40.2 \%$ in 2013 and 51.9\% in 2015, and numeracy standing at $41.4 \%$ in 2013 and 52.6\% in 2015 (National Planning Authority (NPA) 2015; Ministry of Finance Planning and Economic Development (MoFPED) 2016; Ministry of Education and Sports (MoES) 2017). The completion rate for primary education stood at $61.6 \%$ in 2017 with $7.2 \%$ of pupils failing to move up a class each year (MoES 2017). The pass rate for the Primary Leaving Examinations (PLE) stood at 86\% and this was attributed to the low numeracy and literacy levels at Primary 6. Notably only $8.6 \%$ of candidates in the eastern region (our study region) obtained division 1 grades in the PLE in 2015 (Office of the Prime Minister (OPM) 2016). There are also geographical disparities in performance. The northern and eastern regions of Uganda perform worse than the central and western regions, and urban schools perform better than rural schools (Oluka and Opolot-Okurut 2008). In almost all regions, privately owned schools perform better than public primary schools; with one possible key factor being a lack of commitment of teachers in public schools characterised by teacher absenteeism from school (Mwalimu 2016; IOB 2008; World Bank 2017).

The present study was conducted among managers of primary education in Eastern Uganda and offers insights which may help government to address governance issues affecting primary education.

In their 2008 study, Oluka and Opolot-Okurut identify factors which they considered responsible for poor performance of primary school pupils in Uganda's Teso region. These factors include elements which are school-based, teacher-based, parents-community, curriculum-related, pupil-based and policy. School-based factors include insufficient infrastructure and limited learning materials. Teacher-based factors consist of authoritarian teaching practices, discrepancy between time allocated to learning and time actually spent on learning, limited application of continuous assessment of pupils, limited communication between parents and schools, and limited community involvement in school programmes. Curriculum-related factors include inadequate teachers' guides, teachers' failure to understand the primary school syllabus, and poor working conditions. Pupil-based factors were listed as low learning ability, low reading ability, a lack of midday meals, limited time spent on homework and inequitable pupil-teacher ratios. Policy factors cited included an uncoordinated transfer policy for teachers, lack of a lunch policy, automatic promotion of pupils at the end of the year, and limited teacher motivation.

While Oluka and Opolot-Okurut (2008) identify these factors, they do not, however, establish their underlying causes. Decentralised governance and the numerous reforms of Ugandan primary education were implemented to help solve some of these challenges. Since decentralised governance of primary education began in 1998, it is the District Education Committee (DEC), answerable to the District Council and the Ministry of Education and Sports, which recruits and deploys teachers, monitors and supervises schools, and facilitates SMCs - rather than the Ministry which had previously. The present study explores school managers' perception of how decentralised governance of primary education has impacted the performance of primary school pupils. 


\section{Background, literature review and policy context}

The UN's Millennium Development Goals, succeeded in 2015 by the Sustainable Development Goals, aimed at enabling all children of primary school age worldwide to complete the primary school cycle, and for boys and girls to have equal access to education at all levels. This agenda was in line with the Government of Uganda's universal primary education (UPE) policy instituted in January 1997, which allowed all pupils to access education. UPE provides for 'free' education to all children of primary school age (6-13 years) in Uganda. During the 1996 election campaigns President Museveni promised to abolish school fees and meet the cost of primary education for four children per family (Tromp and Datzberger 2019). The UPE was introduced to establish, provide and maintain quality education as the basis for human resource development, transforming society in a fundamental positive way, and provide the minimum necessary resources to enable every child to enroll and remain in school throughout the primary cycle of education. UPE aimed at making basic education accessible to the learner and relevant to his or her needs. UPE was also meant to meet national developmental goals, make education equitable, and ensure that education is affordable and accessible for all Ugandans (Yiga and Wandega 2010; John Paul II Justice \& Peace Centre 2014).

The introduction of UPE led to a huge increase in pupil enrolment in government-aided primary schools, from 2.8 million in 1996 to nearly 8.5 million in 2014 (NPA 2015). In 2012, the gross enrolment ratio ${ }^{1}$ stood at $128 \%$ while the net enrolment ratio ${ }^{2}$ stood at $92 \%$ - compared to under $20 \%$ in 1992 before the introduction of UPE (OPM 2016). The Office of the Prime Minister's 2016 process evaluation established that UPE had made significant progress towards achievement of key objectives such as improving equity in and access to primary education, expanding physical facilities (OPM 2016). The expanded access to primary education has also led to gender parity in primary enrolment (Tromp and Datzberger 2019). However, it has also resulted in very high pupil-teacher ratios, scarcity of classrooms and textbooks, and a reduction in performance of pupils in terms of completion rates, pass rates, numeracy and literacy rates and inequalities if one considers completion rates and quality of education (John Paul II Justice and Peace Centre 2014; Tromp and Datzberger 2019).

In rolling out UPE, the Ministry of Education and Sports has retained many core functions. These include contributing to the construction of basic school facilities such as classrooms and libraries; supervising, monitoring and training teachers (including refresher courses); providing textbooks and teacher guides; evaluating the UPE programme; and providing standards for the curriculum, monitoring and assessment (MoES 2016b). The government abolished all tuition fees, as well as parent-teacher association (PTA) charges for primary education. Consequently, the government provides school

\footnotetext{
${ }^{1}$ Number of students enrolled in a given level of education, regardless of age, expressed as a percentage of the official schoolage population corresponding to the same level of education (http://uis.unesco.org/en/glossary-term/gross-enrolment-ratio).

${ }^{2}$ Total number of students in the theoretical age group for a given level of education enrolled in that level, expressed as a percentage of the total population in that age group (http://uis.unesco.org/en/glossary-term/gross-enrolment-ratio).
} 
capitation and facility grants directly to schools to cover expenditure on instructional materials, extracurricular activities, maintenance and utilities, and administration costs; pays teacher salaries; and meets non-wage expenditure (Reinikka and Svensson 2004). Donor agencies and district councils also contribute to financing primary education, and overall, $60 \%$ of education funding at local government was spent on teachers in 2013/2014, followed by recurrent expenditure (16\%), wages for non-teaching staff $(11 \%)$, capital investment $(8 \%)$ boarding, health and meals $(3 \%)$ and learning and teaching materials (1\%) (MoES 2016b).

Since the introduction of decentralised governance the implementation of primary education has been the joint responsibility of the District Education Committee, of which the district education officer (DEO) is the secretary, and local communities. The DEO is answerable to the District Council and the Ministry of Education and Sports. The district staff (DEO and inspectors) are responsible for staffing primary schools. Mwalimu (2016) notes however that the quality of teachers is still low, and this contributes to the poor quality of education. Equally UNICEF (2020) notes that "teacher absenteeism and under-qualification of many teachers spell disaster for children " in Uganda (p. 1). While the pupilteacher ratio has improved over time from 52:1 in 2003, to 49:1 in 2009 and 46:1 in 2013, teachers are still few in number and have heavy workloads with the pupil-teacher ratio at 42.7:1 in 2017 (Uganda Bureau of Statistics 2017; Mwalimu 2016). This is compared to the world average of 21.8 and African average of 34.3 pupils per teacher in 2017 (The Global Economy 2020). Teachers are unequally distributed among schools without regard to the ratios, and schools with similar numbers of pupils may have widely differing numbers of teachers (NPA 2015). Further, Uganda has never achieved a fair or even distribution of teachers across the country, and decentralised management has worsened the situation; some districts continue without functional District Service Committees meaning additional teachers cannot be recruited (NPA 2015). Teacher absenteeism stands high at 20-30\% (NPA 2015) and those attending school may not be teaching in class (World Bank 2017).

The DECs and their staff have a number of statutory responsibilities: implementing government education standards and policies; monitoring and supervising schools to ensure quality; distributing, controlling and accounting for funds allocated to the education sector by the district council; and ensuring good performance and quality of learning in their district. However, school inspection, monitoring and supervision is inadequate; and primary schools are poorly managed due to inadequate staffing at national and district levels, limited budgets and overlapping central and local mandates (NPA 2015). The same report emphasises that school inspection is weakest at the local government level due to inadequate numbers of staff, skills and budget.

A further complicating factor is that, under decentralised governance, community leaders are also responsible for monitoring and supervision. In Bukedea district, for instance, local leaders including local councils, religious leaders and district and sub-county staff tried to conduct periodic monitoring 
visits but were hampered by lack of transport and inadequate support (Nanyonga and Nanziri 2013). Supervision and inspection of schools is in general still inadequate despite the decentralisation of education management, and that community participation in primary education has declined since the launch of UPE (NPA 2015). A later study by Ocan (2017) confirmed that community involvement is school activities is low, as only $21.7 \%$ of the community members who participated in the study were involved in school activities. Efforts to engage communities in monitoring school activities are hampered by low interest among community members, poor facilitation and a perception that primary education is purely the responsibility of government (NPA 2015).

On the other hand, in 1998, government reintroduced SMCs as a legal entity at the school level to represent government and formally take control of decentralised education (MoES 1998, cited in Prinsen and Titeca 2008). The SMCs control all recurrent income and expenditure of the schools and are tasked to ensure proper and efficient management in accordance with government policy (Asiimwe and Nakanyike 2004). Since conditional grants were introduced, the SMCs spend the funding according to government specifications, namely $50 \%$ on instructional materials, $30 \%$ on co-curricular activities, $15 \%$ on utilities and maintenance and 5\% on administration (Prinsen and Titeca 2008). SMCs are also responsible for supervision of teacher and pupil attendance, teacher performance, monitoring the utilisation of school funds and ensuring that parents contribute towards pupils' midday meals. However, studies have shown that most SMCs fail (Prinsen and Titeca 2008; Nanyonga and Nanziri 2013; MoES 2017). Some SMCs have been informally captured by politicians, some who have been found to use their political influence to channel resources to particular schools, or by dominant individuals in society who may be the community representative on many institutional committees (Reinikka and Svensson 2004; Prinsen and Titeca 2008). Furthermore, most SMC members are not active and do not know their roles and responsibilities (Nanyonga and Nanziri 2013; MoES 2017).

Under UPE, parents are expected to provide exercise books, pens, uniforms and lunch. However, Nanyonga and Nanziri (2013) show that in Bukedea district, parents cannot always contribute towards midday meals for their children even when they know that it is their responsibility. Ezati et al. (2016) notes that in northern Uganda there are several factors that contribute to parents' limited involvement in children's education including "poverty, dislocation, fear, alcohol consumption, and misunderstanding of policy" (p. 10). Some northern Ugandan parents fail to provide exercise books for their children and textbooks for both teachers and pupils because they cannot afford them (Oluka and Opolot-Okurut 2008). The absence of textbooks affects both teaching and learning, compromising the quality of education. For example, the 2019 UWEZO annual assessment report showed a decline in numeracy and literacy levels of primary 3-6 pupils. "The percentage of P3-P7 children who could read and comprehend a basic story at P2 level dropped from $39 \%$ in 2015 to $33 \%$ in 2018 ", while those who could do P2 division dropped from 52\% in 2015 to $45 \%$ in 2018 (UWEZO 2019). 
Indeed, the national government's budget speech 2015/2016 indicates that the education sector in Uganda still faces challenges in delivering quality education in an efficient manner, despite decentralised governance. For instance, the UWEZO report 2019 shows that proficiency in numeracy and literacy has been declining with the percentage of P3-P7 children who could read and comprehend a basic story at P2 level dropping from 39\% in 2015 to 33\% in 2018. Also, the percentage of P3-P7 children who could do P2 division dropped from $52 \%$ in 2015 to $45 \%$ in the same period (UWEZO 2019). The retention rate from Primary 1 to Primary 5 declined marginally from $60.6 \%$ to $59.9 \%$ between 2014 and 2015, and that from Primary 5 to Primary 7 declined from $32.9 \%$ to $30 \%$ in the same period (MoFPED 2016). The decline in proficiency and retention of pupils was attributed to persistent absenteeism, late reporting, and early departure from work by teachers, and the low level of salaries paid to teachers and head teachers (MoFPED 2016; World Bank 2017). This again confirms that teachers heavily influence the performance of pupils.

The national measure for primary completion - namely, cohort survival rate to Primary 7 in 2015 stood at only $30.1 \%$ (MoES 2017) meaning that the dropout rates are high at upper primary which results in low transition to secondary level education. Notably the transition rate from Primary 7 to senior one (S1) increased by $12.3 \%$ from $50.9 \%$ in 2007 to 63.2\% in 2015 (MoES 2017). The government has attributed this to inadequate school monitoring and teacher supervision; inadequate community participation through SMCs and PTAs and under-funding of primary schools (OPM 2016; MoES 2017).

The quality of primary education is also reflected in Uganda's Primary Leaving Examination (PLE) results. For instance, in 2015, 621,401 pupils registered for the PLE but only 601,777 actually sat the exams and 600,868 were graded. Analysis of the 2015 PLE results shows that only 517,895 candidates passed, of which only $8.6 \%$ were in division 1 (the top band) and $39.0 \%$ in division 2 . Another $38.6 \%$ fell in divisions 3 and 4, while 82,972 (13.8\%) pupils did not pass (MoES 2016a). This shows that the great majority of pupils pass in divisions 2,3 and 4 - which are not grades for entry into top secondary schools in the country.

The performance of primary education is also characterised by regional disparities. Although UPE has equalised access to education, it has not equalised education quality and performance (Higgins 2009). For example, the World Bank's (2012a) study on poverty trends in Uganda as well as the study by Essama-Nssah (n.d.) have found that the eastern and northern regions in Uganda have the highest pupilteacher and pupil-classroom ratios compared to their counterparts in central and western regions and this points to a wide variation in the quality of primary school education.

Urban schools also perform better than rural schools, and private schools tend to perform better than public schools. Private schools have relatively better school management which leads to higher pupil and teacher attendance, better motivated teachers, better management of resources and a better school environment (NPA 2015) and good school management is necessary for improved school outcomes. 
There are several documented governance challenges facing education systems in Sub-Saharan Africa, including lack of funding, inadequate infrastructure especially in rural areas, insufficient qualified and motivated teachers, lack of qualified education managers, inadequate policy frameworks, inequality issues, lack of participatory decision-making, and difficulties in implementing appropriate accountability and supervision systems (Baghdady and Zaki 2019; Kadir 2019). For instance in Cameroon primary education has been characterised by poor quality standards and disparities between rich and poor, boys and girls, rural and urban areas, and regions (World Bank 2012b). This report suggested that challenges faced by the education system in Cameroon are significantly linked to governance and management issues, concluding that "accountability for school functioning and performance is weak and the monitoring of teachers' performance in the classroom is fractured and ineffective" (p. 1). Resource allocation was ineffective, and citizen participation had little impact, both of which affected performance in primary schools.

Uganda is therefore not alone in having a governance dilemma in the management of primary education. Despite the stated partnership between policy-makers, implementers and beneficiaries in its decentralised governance, there is declining performance and quality of primary education. Although stakeholders at local districts, schools and parents are expected to contribute towards attaining education goals, these beneficiaries are under-researched and neglected in terms of documenting the critical contribution and views about their impact (Okurut-Ibore 2015).

With this backdrop in mind, this study seeks to analyse in what ways school managers feel decentralised governance of primary education affects performance outcomes.

\section{Methodology}

The study was conducted among primary school managers (comprising district education officials, head teachers and deputy head teachers of primary schools) in the districts of Bukedea, Tororo, Budaka and Butaleja in the eastern region of Uganda. These managers were participating in a World Bank-funded project entitled the Global Partnership for Education (GPE), organised by the MoES and implemented by the Uganda Management Institute, where the author is a research academic. The GPE is a leadership and management capacity-building course targeting school managers in public schools in all regions of the country.

The spur for the present research was the first interaction of the author with one of the GPE classes in Bukedea training centre. Within this class of 45 school managers, only six had students who had obtained any division 1 results in the 2015 PLEs. The managers attributed this to poor governance of the education system. One went so far as to say that "if there is something detrimental this government has done to this country, it is to decentralise the education sector". This stark statement triggered the author's awareness of the need to investigate the link between decentralisation and performance in primary education. 
The four districts studied were selected for convenience, because they converged at Bukedea training centre, where the author was a trainer. School managers as a group were selected on the basis that they were present at the training centre and willing to participate in the study. It was felt that school managers were also the right category of respondent because they are in close contact with many education stakeholders: teachers, parents, the community and learners, among others. They therefore had up-todate first-hand experience and information pertaining to decentralisation of primary education and pupil performance. The study comprised 104 participants, 68 male (65.4\%) and 36 female (34.6\%); the unequal gender split arose because leadership positions in primary schools are largely occupied by men. Almost half of respondents (56/53.8\%), were aged 40-49 years, and a quarter (27/25.9\%) were aged $50+$ years; there was only one $(1.0 \%)$ respondent in the 20-29 age bracket with the remaining 21 (20.1\%) being 30-39 years. This age distribution reflects that headship in schools is mainly awarded to more mature teachers.

The research adopted a two-phased qualitative approach. The first phase was an exploratory study designed to establish whether education managers believed decentralised governance of primary education has enhanced pupils' performance. This phase was also used to examine whether school managers thought primary education should be recentralised. The data in the first phase was captured using a questionnaire survey. Self-administered questionnaires were distributed to 150 participants and returned by 104 respondents (69.3\%) and aimed at establishing why education managers thought decentralised governance had or had not improved performance of pupils in primary schools

The results from the first phase informed the second phase which sought to establish the rationale for the education managers' views on decentralised governance. Data for the second phase was drawn from the same respondents, using semi-structured self-administered questionnaires. Additionally, in the second phase in-depth semi-structured interviews were conducted in each of the four districts with two district education officials: the DEO and the district inspector of schools (DIS) - making a total of eight interviews. These district officials were purposively selected as key informants because they were frequently cited by head teachers and deputy head teachers during informal discussions as appropriate persons to give a reliable overview of the effect of primary school decentralised governance on pupil performance. Combining a semi-structured questionnaire and in-depth interview guide to collect data can help provide broader and more in-depth insights into the governance of primary education. The data captured from the semi-structured questionnaires was coded using Excel and analysed by thematic analysis. Raw data drawn from semi-structured questionnaires and in-depth interviews were studied, using Excel to code and develop patterns from it across different interviews and questionnaires. Thereafter themes were developed as reflected in the headings and subheadings in the findings and discussion section below. 


\section{Study findings and discussion}

The results show that just over half of the respondents (56/53.8\%) believed decentralisation of primary school education had not enhanced performance of pupils, but also, interestingly, just under half $(48 / 46.1 \%)$ felt it had improved performance. On the question of whether primary education should be recentralised or not, again it was a split in views, with less than half (41/39.4\%) agreed to the suggestion, while $(63 / 60.6 \%)$ did not. Therefore, although a majority - albeit a slim one - of managers claimed that decentralised governance had not enhanced performance, a larger majority nevertheless wanted to retain it. The views expressed are therefore nonconclusive. This section explores the findings in more detail to establish how these conflicting views are realised, and whether they can be reconciled.

\section{Perceived benefits of decentralised governance of primary education}

A large proportion of respondents (76.9\%) did report that decentralised monitoring and evaluation has in some ways improved performance of pupils. It has eased school monitoring and supervision, enhanced access to and management of teacher welfare services, and increased ownership and involvement of communities in school programmes (see Table 1).

Table 1: Perceived benefits of decentralised governance of primary education

\begin{tabular}{|l|c|c|}
\hline Perceived benefits & $\begin{array}{c}\text { Number of } \\
\text { responses } \\
\text { (out of 104) }\end{array}$ & $\begin{array}{c}\text { Percentage } \\
\text { (\%) }\end{array}$ \\
\hline Enhanced school monitoring and supervision & 80 & 76.9 \\
\hline $\begin{array}{l}\text { Easier monitoring, supervision and evaluation of service delivery of school } \\
\text { programmes }\end{array}$ & 23 & 22.1 \\
\hline $\begin{array}{l}\text { Teachers taking greater responsibility for results - eg following up on children who } \\
\text { do not regularly attend school }\end{array}$ & 38 & 36.5 \\
\hline $\begin{array}{l}\text { Local leaders taking greater responsibility for results - eg monitoring and reporting } \\
\text { cases of absenteeism }\end{array}$ & & 76.0 \\
\hline Enhanced access to and management of teacher welfare services & 79 \\
\hline $\begin{array}{l}\text { Delivery of salaries and services nearer to civil servants/teachers, making it easy } \\
\text { to correct payroll issues }\end{array}$ & 56 \\
\hline Easier and faster to manage and access payroll services & 45 \\
\hline Faster feedback on local education issues and programmes & 43.8 \\
\hline $\begin{array}{l}\text { Enhanced ownership and involvement of communities in school } \\
\text { programmes }\end{array}$ & & 73.2 \\
\hline $\begin{array}{l}\text { Greater involvement of stakeholders in school programmes, fostering community } \\
\text { ownership and increasing performance of learners }\end{array}$ & 36 \\
\hline $\begin{array}{l}\text { Desire by locally born teachers to boost educational performance of their home } \\
\text { area, meaning they give more support to pupils }\end{array}$ & 46 \\
\hline Increased local autonomy via the introduction of SMCs & 34.6 \\
\hline
\end{tabular}

Source: Primary data from fieldwork

For example, it was felt that decentralised governance has increased the regularity of inspection and provides opportunity for inspectors to engage and advise pupils and teachers. The district inspectorate can conveniently and ably get to the furthest schools in the district and can spend ample time with pupils and teachers to understand issues in a given school. 
One respondent affirmed this:

It has brought about quick monitoring, assessment and controlling situations at primary schools. Inspectors come and advise and when it is necessary, they can make more than one visit in a term. For instance, some teachers are warned against absenteeism (participant from Bukedea district).

Another participant from a different district echoed this observation:

Effective inspection, supervision and monitoring of schools and education programmes has made teachers improve their teaching methods and upgrade their careers. Even when inspectors meet pupils, they are able to advise them on their performance and obligations in schools. This has often encouraged pupils to work hard (participant from Budaka district).

Pupils' and teachers' attendance is monitored, and those who have a habit of dodging lessons can be reprimanded. While literature (see NPA 2015) suggests that inspection, monitoring and supervision is inadequate, according to the findings above, the little that exists is viewed by the respondents to be well carried out and inspectors dedicate more time to advising school actors than before.

Respondents also felt the participation of local leaders and teachers in monitoring has improved attendance of pupils and retention of children from one year to the next. Decentralised monitoring and supervision have reduced absenteeism, and this was cited in the responses as one of the reasons some primary schools in eastern Uganda were beginning to register improved performance. Although participation of local leaders in supervision and monitoring of primary education is low (Nanyonga and Nanziri 2013; NPA 2015; MoES 2017), evidence suggests that the little that does take place contributes to retention of children and reduces teacher absenteeism.

Decentralised governance also minimises the time that teachers spend on administrative issues and enables them to spend more contact time with pupils. For example, teachers no longer have to spend their meagre resources on travelling to the centre to deal with payroll issues. A study respondent said:

Management of teachers' payroll at the district has reduced the expenses of travel to the headquarters (central government) just for correction of payment issues. Teachers do not have to miss lessons, which can translate into better performance of schools (participant from Butaleja district).

However, the NPA did note in its 2015 report that this has had a downside of additional 'ghost' (nonexistent) teachers, pupils and schools and is likely to undermine efficient use of resources. Additionally, while teachers may have more time, this does not necessarily translate into more teaching. An earlier report on the impact of universal primary education had estimated teacher absenteeism to be $20 \%-30 \%$ (IOB 2008). The newly streamlined payroll system does not however guarantee regular payment of salaries, or regular salary increases, as payment still depends on central government releases. Indeed almost half (45/43.3\%) of respondents noted that teachers do not always work diligently - even if they get their pay on time - simply because the working conditions are still inadequate. This is supported by the NPA analysis (2015) which shows that although budget allocation to the education sector has been 
increasing in nominal terms, the wage bill has remained stagnant and the small increment available has been affected by inflation. As such, teacher welfare is poor and has been a cause of numerous strikes in schools, which have negatively affected teaching and learning (Namara and Kasaija 2016).

Decentralisation has made it easier for educators to access and consult top officials such as the Chief Administrative Officer and the District Service Commission. For example, the information management system at the district is open to head teachers so they can verify information regarding teachers and administrators, and teachers' and other employees' grievances are more easily and more quickly handled at district level. Devolving information management to district level has therefore brought some benefits, but it has also created duplication as the same information can be captured by several ministries, including public service, local government, and education and sports (NPA 2015).

Decentralised governance has also given parents and other stakeholders a say in school matters, which enhances concerted efforts towards better performance. As one respondent commented:

Decentralisation has enabled some school programmes to be run by the PTA, SMC - such as organising testing exercises for continuous assessment of learners in UPE (governmentaided schools), thereby exposing pupils to the exams done by other districts. The involvement of SMCs is an important feedback mechanism to the schools on the regular performance of pupils and what parents think (participant from Bukedea district).

However, research has shown that community participation in primary education is still low, and that communities were still taking insufficient 'ownership' of local schools. SMCs - structures in which parents are expected to be involved - are reported as having failed to succeed (Nanyonga and Nanziri 2013; MoES 2017).

Study participants felt that the employment of people born in the local area as teachers and administrative staff enhances ownership. Some perceived that 'native' teachers are more motivated to boost education standards in the district, since it is their own community. One respondent noted:

The last PLE results were better than before since the teachers who were recruited are from within the area and region. Teachers from within the community tend to be more committed to the children than those from other districts (participant from Tororo district).

Another commented:

Teachers are working more effectively since they are nearer their homes and places of birth and can therefore easily handle family problems in time, making them more comfortable. This translates into better performance at work since they spend most of the time at school and this can improve grades at school (participant from Budaka district).

Recruitment and deployment of 'native' teachers provides local employment for teachers; so in general they should be closer to their home and therefore able to give more time to school activities, leading to better PLE performance. However, the poor PLE grades achieved in eastern Uganda do not necessarily support this assumption, and further study is to examine this relationship. 


\section{Perceived disadvantages of decentralised governance of primary education}

Several concerns were raised in relation to decentralised governance of primary education, as listed in Table 2. These included nepotism, intimidation, politically motivated transfers of teachers and headteachers, and poor monitoring and supervision. Although decentralisation was commended for increasing opportunities to employ 'native' (i.e. locally born) teachers, and also to boost ownership of school programmes, respondents also had concerns over increased nepotism, which is seen to have a negative impact on performance. Not only does nepotism makes supervision and accountability difficult - since workers failing to perform up to expectation are less likely to face sanctions - it also has results in the deployment of inexperienced teachers, who remain cocooned in their districts of origin and fail to gain necessary experience in a range of environments. Such appointees can lack role models and exposure to new ideas, can be subject to limited benchmarking, and face no competition.

Table 2: Perceived disadvantages of decentralised governance of primary education

\begin{tabular}{|l|c|c|}
\hline Perceived disadvantages & $\begin{array}{c}\text { Number of } \\
\text { responses } \\
\text { (out of 104) }\end{array}$ & $\begin{array}{c}\text { Percentage } \\
\text { (\%) }\end{array}$ \\
\hline Decentralised governance has bred nepotism and job-related conflict & 89 & 85.6 \\
\hline $\begin{array}{l}\text { Nepotism has held back performance because good teachers from other } \\
\text { tribes/districts are excluded from recruitment }\end{array}$ & 35 & 33.7 \\
\hline $\begin{array}{l}\text { There is lack of exposure of 'native' teachers to wider teaching experience and } \\
\text { ideas }\end{array}$ & 35 & 33.6 \\
\hline $\begin{array}{l}\text { Under decentralised governance, political leaders tend to exert undue influence } \\
\text { on schools' administration }\end{array}$ & 67 & 64.4 \\
\hline $\begin{array}{l}\text { Increased opportunity for politicians to interfere in the education system (e.g. by } \\
\text { arbitrarily transferring teachers, head teachers and district education officers) } \\
\text { which compromises performance of schools }\end{array}$ & 19 & 18.2 \\
\hline Some district officials lack respect for teachers & 20 & 19.2 \\
\hline $\begin{array}{l}\text { Many teachers and school managers are demoralised because their } \\
\text { appointments are on an 'acting', not 'substantive', basis }\end{array}$ & 36 & 34.6 \\
\hline $\begin{array}{l}\text { Staff deployed to monitor and supervise the teaching and learning process are } \\
\text { not trained for this role }\end{array}$ & 33 & 31.7 \\
\hline
\end{tabular}

Source: Primary data

As a result of nepotism, school leadership and management bend regulations to avoid antagonising relatives, friends or politicians. Beneficiaries of nepotism are more likely to absent themselves, fail to complete the syllabus, or refuse to implement school regulations. $44 \%$ of respondents felt that nepotism fosters selfish behaviour, rather than unity to promote performance, yet there is limited supportive supervision. One respondent observed:

Nepotism and tribalism have made job opportunities so hard to get in the education sector. This is because even those who commit crime are never apprehended or penalised because [those in charge] employ relatives. Most employees are related to one another so no one can ably supervise and deliver the findings of inefficiency genuinely to government (participant from Bukedea district). 
Another echoed:

Me, as a head teacher, I have nothing [I can] do to ineffective teachers. This is because I see them come and I see them go. Am not consulted when they are being employed or deployed or redeployed. Even then, if these teachers are relatives to some politicians, then as a head teacher you have to be careful the way you handle them otherwise you will lose your job (participant from Tororo district).

Nepotism has also increased corruption in the recruitment process. As two respondents commented:

It has raised corruption, since the top managers look at their own people when it comes to key offices, even when they do not have the relevant qualifications (participant from Butaleja district).

It is common practice that officials are compromised by the non-performers since they are their relatives or kinsmen whom they gave jobs (participant from Budaka district).

These findings echo those of the NPA (2015) that decentralisation has worsened teacher deployment and utilisation, in the sense that there is limited openness and fairness in recruitment.

Teacher recruitment policy was also criticised. The existing policy allows enrolment of general primary teachers rather than subject specialists, and anyone qualified as a primary teacher can teach any subject at primary level. This compromises the quality of the knowledge imparted to pupils, as teachers do not focus on particular subjects. One district education official expressed their dissatisfaction on this point thus:

To us recruitment is informed by the number of children a given school has. When we advertise in government we do not specify that we need a specialist in [for example] English. We say we need a primary school teacher. Therefore, you may find a school has more science teachers and there may be no teacher of English... This is not happening in private schools, for they are specific on the skills they are interested in (participant, district official).

While it is important for teachers to be multi-skilled, the current recruitment and deployment practice seems to compromise the quality of learning because 'general' teachers may not understand the curriculum in specialist areas, and may thus be forced to deliver 'half-baked' content (Oluka and Opolot-Okurut 2008; Mwalimu 2016).

Decentralised recruitment and deployment have also increased the number of arbitrary transfers of teachers and managers, which hinders them from consolidating their work, and impacts learning. Discussions with district officials and school managers revealed a couple of factors driving these transfers. Politicians, PTAs and SMCs tend to lobby DEOs for the transfer of teachers they are not comfortable with. Reasons given include poor teacher performance, or even unprofessional behaviour such as alcoholism or harassment of pupils. If these transfers are not implemented by the DEO, politicians - through councils - complain, for example, of imaginary collusion between the DEO and the teachers or head teachers, aiming to cause fear and tension among DEOs and forcing such officers to lose their jobs. As a result, DEOs often implement transfer directives made by politicians or even councils. 
As noted by one district official:

Our role is to advise politicians to follow education policies and standards, but our hands are tied and we fear to antagonise politicians. Sometimes they misguide parents and you find everyone is against you because you are insisting on implementing a policy (participant, district official).

Although the existing literature does not allude to teacher intimidation as a cause of teacher attrition, discussions with district officials in this research indicate that it is one of the reasons why teachers resign. This in turn contributes to high pupil-teacher ratios. Nationally, Uganda's teacher attrition rate was estimated to be 5\% per year in 2010 (Haddad and Adubra 2010).

More generally, this study found that politicians exert considerable influence on school administration. This resonates with findings by Reinikka and Svensson (2004) and Prinsen and Titeca (2008) that politicians have informally captured SMCs to access resources from particular schools. Although these scholars emphasised the capture of financial resources, politicians' influence affects management of human resources as well. District officials have also been reported as intimidating teachers and head teachers; for example, teachers are liable to face insults if they go to district offices with complaints or other official issues. One teacher lamented:

The officials actually 'own' the district and can do anything to you as a teacher. We are at their mercy (participant from Tororo district).

The intimidation and insults demotivate the teachers and compromise teaching and learning, resulting in poor performance of pupils.

Working in an 'acting' capacity as a school manager also seems to compromise governance and accountability and decrease performance. This is because head teachers cannot assert themselves or exercise full powers while in an 'acting' capacity. District officials noted that confirming head teachers or their deputies in post requires additional funding for salaries and wages. Although the education budget expands every year in nominal terms, it has been declining in real terms (NPA 2015) meaning that little money is available for confirming staff posts.

Monitoring and supervision were seen by many as poor, characterised by unqualified monitors and supervisors. For instance, stakeholders from school foundation bodies such as SMCs and PTAs, as well as those assigned to inspect schools, may not always be up-to-date on the education system and the latest government policies. Due to varied training, knowledge and capacity, they may make incorrect judgements and observations during supervision of schools, and give poor guidance to school managers. 
As three respondents noted:

There is no proper training for the SMC/PTA members; they lack knowledge and skills due to lack of capacity-building and leadership training (participant from Bukedea district).

A lot of operations are left in the hands of stakeholders, yet they may not be well versed in government policies and operations - making it hard for the programmes to run efficiently. As a school manager you get all sorts of advice which may not be in line with required standards (participant from Tororo district).

There are undefined policies in the education sector - such as the unqualified monitors and supervisors who are mandated yet know nothing about education. The likes of the politicians, who are even supported by the central government, have jeopardised the education system and operations, undermining performance in these schools (participant from Budaka district).

The assumption that anyone can monitor, inspect and supervise primary education without necessarily being equipped with guidelines and tools has further weakened the monitoring function. It is therefore not surprising that the 2015 NPA report indicated school supervision is weakest at local government level. Okurit-Ibore (2015) maintained the need for stakeholder dialogue at district, school and community levels so as to increase stakeholders' capacity and commitment to education.

\section{Other factors affecting performance of primary education}

The study also sought to establish other factors beyond decentralised governance that have contributed to poor performance of primary schools in the districts of study. Table 3 indicates the wide range of factors cited, including high pupil-teacher ratios and overcrowded classrooms, poor and delayed salaries, misinterpretation of government education policies, and negative attitudes and culture towards education.

Table 3: Other factors affecting performance in primary education

\begin{tabular}{|l|c|c|}
\hline Other factors contributing to poor performance of pupils & $\begin{array}{l}\text { Number of } \\
\text { responses } \\
\text { (out of 104) }\end{array}$ & $\begin{array}{c}\text { Percentage } \\
\text { (\%) }\end{array}$ \\
\hline $\begin{array}{l}\text { Teachers are demoralised due to delayed salaries even after decentralisation } \\
\text { of payments }\end{array}$ & 56 & 53.8 \\
\hline $\begin{array}{l}\text { General negative attitude towards education among parents, other } \\
\text { stakeholders and learners }\end{array}$ & 52 & 50.0 \\
\hline Parental negligence, eg failure to provide pupils with midday meals & 45 & 43.3 \\
\hline High pupil to teacher ratio and overcrowded classrooms & 45 & 43.3 \\
\hline $\begin{array}{l}\text { Remuneration for teachers is too low, meaning good 'native' teachers move to } \\
\text { other districts where parents top up salaries }\end{array}$ & 44 & 42.3 \\
\hline $\begin{array}{l}\text { Lack of midday meals at school makes it hard for teachers and pupils to } \\
\text { concentrate on the teaching/learning process }\end{array}$ & 39 & 37.5 \\
\hline
\end{tabular}

Source: Primary data from fieldwork

Inadequate infrastructure to support the large school-age population is an issue that government has been grappling with. For some schools, learning is still taking place under trees and lessons are interrupted when it rains, resulting in failure to complete syllabi due to loss of time, demotivation of 
learners and high drop-out rates. The NPA 2015 report and the OPM in 2016 both attribute the high pupil-teacher ratio to the increasing population, but some districts lack enough funding to recruit enough staff and those left can do nothing except cover the work of those who leave (NPA 2015), yet $70 \%$ of local government education funding is still said to be spent on teachers' salaries (MoES 2016b) an indication that the available funding is still a constraining factor.

Some good teachers move, looking for greener pastures, in some cases due to a lack of adequate accommodation at schools (Oluka and Opolot-Okurut 2008) and a lack of midday meals - the latter causing teachers rush to their homes after teaching or during lunchtime, leaving learners less time to consult and revise with them. As noted by a respondent:

Lack of teachers' accommodation; by the time teachers arrive they are already too exhausted to deliver effectively (participant from Bukedea district).

Another echoed:

Teachers in most cases have to leave school at lunchtime in the name of looking for lunch and do not return for the afternoon sessions (participant from Tororo district).

This, combined with lack of midday meals for children, was seen to have contributed to poor performance in some primary schools.

Another important factor is parents' neglect of their role in education. Parents are said to have negative attitudes towards supporting and supplementing government efforts, for example by feeding learners at school and providing the necessary scholastic materials: books, pens, uniform. If pupils absent themselves, parents also may not reprimand them or encourage them to attend school. Nanyonga and Nanziri (2013) also found that parents in Bukedea district, for example, were not able to contribute towards midday meals for children even when they knew it was their responsibility. Consequently, children miss some classes and others may drop out because of patchy attendance. As a respondent noted:

High rate of absenteeism on the side of the learners makes it hard for the learners to perform since they miss a lot of lessons (participant from Budaka district).

There are of course further factors. These include girls' failure to attend school during the menstrual cycle, especially those who have no sanitary supplies provided by their parents (Miiro et al. 2018). A further factor may be parents believing that the government should give the learners everything, from food to scholastic materials and uniform. Further, some parents marry off their young daughters of school age to older men, to get a few heads of cattle (Oxfam and We-Care 2018). This not only affects completion rates of primary education, but also the attitudes of children towards education. 
Some teachers have a negative attitude towards teaching because they do not earn enough money to improve their livelihoods and therefore undertake teaching as a side occupation. Teachers in this situation develop poor customer care and a general lack of concern for pupils' performance. As one respondent noted:

The stakeholders, including teachers and administrative staff, have a negative attitude towards school programmes since they do not yield money enough to sustain them; it is more of voluntary work. They even fail to pay school fees for their children to attend good schools. Teachers cannot even afford medical fees for their families and are expected to do miracles in terms of performance (participant from Tororo district).

Unemployment among educated youth also demotivates pupils from completing their education, since better education may not immediately translate into a job. One respondent pointed out:

Even the learners have developed a negative attitude towards education; all they see in education is to enable them get white-collar jobs on completion. Yet the situation has been different since their bigger relatives who may have completed school are in the villages idle and drinking 'ajono' [local millet brew] (participant from Bukedea district).

\section{Reasons for preferring decentralised governance, despite its shortcomings}

Taking everything into account, however, as noted at the start of this paper most respondents did support decentralised governance of primary education. When asked why, the author found that this appears to be principally for practical reasons, which are listed in Table 4 below.

Table 4: Reasons for preferring decentralised governance, despite its shortcomings

\begin{tabular}{|l|c|c|}
\hline Factors in support of decentralised governance of primary education & $\begin{array}{c}\text { Number of } \\
\text { responses } \\
\text { (out of 104) }\end{array}$ & $\begin{array}{c}\text { Percentage } \\
\text { (\%) }\end{array}$ \\
\hline $\begin{array}{l}\text { Problems related to payroll are easily and quickly solved since they are handled } \\
\text { at district level }\end{array}$ & 68 & 65.3 \\
\hline $\begin{array}{l}\text { Recruitment of teachers is done locally, allowing districts to source desired } \\
\text { abilities, knowledge and skills }\end{array}$ & 64 & 61.5 \\
\hline Salaries are released on time & 63 & 53.6 \\
\hline $\begin{array}{l}\text { Inspection, monitoring and supervision of school programmes and activities has } \\
\text { been made easier and is done more regularly }\end{array}$ & 56 & 40.4 \\
\hline $\begin{array}{l}\text { Decentralisation has brought employment opportunities to local communities } \\
\text { which enables more teachers to be absorbed in the system }\end{array}$ & 42 & 22.1 \\
\hline $\begin{array}{l}\text { Establishment of more primary schools, reducing the distances pupils have to } \\
\text { travel }\end{array}$ & 23 & 20.2 \\
\hline More classrooms have been constructed and more teachers recruited & 21 & 15.4 \\
\hline Easy access to district officials since they are locally based & 16 & 15.4 \\
\hline Local stakeholders are now are playing a big role in running schools & 16 & 11.5 \\
\hline Bureaucracy is reduced, allowing more time for delivering education & 12 & 7.7 \\
\hline $\begin{array}{l}\text { Teachers do not have to move away from their homes to work, meaning families } \\
\text { are less likely to be separated }\end{array}$ & 8 & 5.8 \\
\hline Data management and communication are faster and easier & 6 & 5.8 \\
\hline Procurement of school supplies is faster than before and more efficient & & 4.8 \\
\hline
\end{tabular}

Source: Primary data from fieldwork 
Decentralised governance is widely perceived by the study respondents as having improved teachers' welfare. Payroll issues are easily solved at district level and teachers take less time to access the payroll (65.3\% of respondents), salaries are more likely to be paid on time $(60.6 \%)$, districts can employ the teachers they need $(61.5 \%)$, and though reported by few respondents, teachers are more likely to be local (40.4\%), which helps with family cohesion as teachers do not have to move away from their home districts. Additionally, more classrooms have been constructed and more teachers recruited.

A small majority of respondents also felt that decentralised governance has improved inspection, monitoring and supervision of school programmes and activities $(53.8 \%)$, reporting that now more regular and corrective actions are easily undertaken. However, very few (5.8\%) also felt that decentralised governance had eased data capture and communication with stakeholders.

\section{Reflection and conclusions}

Decentralised governance and the administrative reforms that have come with it, such as decentralised management of the payroll and regular monitoring and supervision of primary school programmes, has strengthened the supply side of governance of primary education. Communication and grievance handling are quicker, and teachers are perceived to spend more time in class than before.

Respondents also felt that DEOs do try to follow guidelines in recruitment of staff members, and SMCs follow guidelines in expenditure of conditional grants from central government. The district officials follow up with school managers to ensure they account for the funds and materials they receive and on occasion, the findings suggest that dishonest staff are apprehended if inspectors confirm their culpability. This form of transparency is known as public accountability (World Bank 2010). Public accountability improves control and efficiency in service delivery and is critical to ensure control and enforcement of government standards and policies.

However, the supply side of governance in education in Uganda is nevertheless still riddled with poor practices such as nepotism, intimidation of teachers and school managers, low pay, political interference, transfer of teachers without consultation, and poor monitoring and supervision. These are all barriers to achieving better education outcomes, as they undermine teacher motivation. Certain policy and practice reforms, such as the recruitment of generalist rather than specialised teachers, the purchase and distribution of textbooks which are not requested by schools, and the intimidation of DEOs by politicians, further impede efforts to ensure full public accountability.

Decentralised governance of primary education has however created social accountability structures in the form of SMCs and PTAs. Social accountability is a valuable demand side mechanism to ensure responsiveness of government and improved quality of service delivery. SMCs do appear to have increased participation of parents and other stakeholders in implementation of school programmes. This has boosted the number of stakeholders monitoring school activities, and it was viewed that the performance of school managers as well as learners has to some extent improved because of this. In some instances, the attendance of learners had increased and innovations introduced such as regular assessment geared towards performance improvement. 
This 'demand' side of governance seems, however, to be underdeveloped for the following reasons. Firstly, many SMCs were viewed to have been captured by domineering politicians and very few members of the committees are actively involved. This leads to a second problem, namely that SMC members are not conversant with their roles and responsibilities and do not have the required skills, for instance to conduct monitoring according to government standards and guidelines. A third problem is that other stakeholders involved in monitoring school performance (eg politicians, church leaders and the public) have no clear communication and feedback mechanisms through which to address issues.

The research also suggests that decentralised governance on its own is not sufficient to address poor performance in primary schools in eastern Uganda. This is because other structural factors are also at work. These include inadequate funding, high pupil-teacher ratios, overcrowded classrooms, low and delayed salaries, negative attitudes towards education, and misapplication of certain education policies.

There is therefore a need to strengthen the demand side of governance so as to improve performance in primary schools. This paper recommends a number of measures:

- Strengthening the boards or SMCs of primary schools.

- Undertaking targeted programmes to raise parents' awareness of their responsibilities for example ensuring children's attendance at school, buying scholastic materials, paying school dues promptly, and providing lunch for pupils.

- Reducing unhelpful interference by politicians in governance at the district and school level, by clearly articulating their roles and responsibilities.

- Creating community-based monitoring structures, similar to local council structures in charge of education, on which parents are represented.

- Developing clear reporting and feedback mechanisms between the public and DEOs, which would include the provision of information to the public on school calendars.

In principle, the demand and supply sides of governance should complement each other to find an equilibrium (World Bank 2012b). This paper therefore recommends that reforms on the supply side of primary education in Uganda should also continue, including:

- Establishing a living wage for teachers.

- Introducing a quota for districts in the recruitment of 'native' and non-'native' teachers, to avoid nepotism and expose teachers to different environments and teaching practices.

- Institute a policy to recruit specialist teachers as it is the practice in private schools so as to increase the likelihood of obtaining better pass rates in public schools.

- An increase in UPE funding to offset escalating prices of materials and base the funding on needs.

- A reduction in unplanned or abrupt transfers of teachers, confirmation in post of those working in an 'acting' capacity, and promotion of those who have upgraded qualifications. 
- Continue with other ongoing interventions such as classroom construction, building of teachers' houses, recruiting more teachers, and providing up-to-date textbooks.

- School administrators and teachers should also be trained in how to persuade parents to send their children to school.

\section{Declaration of conflicting interest}

The author declared no potential conflicts of interest with respect to the research, authorship, and/or publication of this article.

\section{Funding}

The author received no financial support for the research, authorship, and/or publication of this article.

\section{References}

Asiimwe, D. and Nakanyike, M.B. (2004) Decentralization and transformation of governance in Uganda. Available at: http://ahero.uwc.ac.za/index.php?module=cshe\&action=downloadfile \&fileid=36807145012101642344134

Badhdady, A. and Zaki, O. (2019) Secondary education governance in Sub-Saharan Africa. Background paper on Education governance in Sub-Saharan Africa: Preparing youth for the future of work. Mastercard Foundation. Available at: https://mastercardfdn.org/wp-content/uploads/2019/03/SEA-Education-Governance-Final_Feb-28-1.pdf

Essama-Nssah, B. (n.d.) Achieving universal primary education through school fee abolition: Available at: https://openknowledge.worldbank.org/bitstream/handle/10986/26712/695190WP0ugand00604020120Box369278B.pdf

Ezati, B.A., McBrien, J.L., Stewart, J., Ssempala, C. and Ssenkusu, P. (2016) Parents, pay attention! Factors related to parental involvement with education in Northern Uganda. Australasian Review of African Studies, 37 (2), 9-32. Available at: http://afsaap.org.au/ARAS/2016-volume-37/ https://doi.org/10.22160/22035184/ARAS-2016-37-2/9-32

Haddad G. and Adubra E. (2010) Teacher attrition in Sub-Saharan Africa. The neglected dimension of the teacher supply challenge. A review of literature and paper prepared for the meeting of the High-level Group on Education for All, Addis Ababa, 9 February 2010. Available at: https://unesdoc.unesco.org/ark:/48223/pf0000188197

Higgins, K. (2009) Regional inequality and primary education in northern Uganda. Policy Brief No 2. Available at: https://www.odi.org/sites/odi.org.uk/files/odi-assets/publications-opinion-files/3377.pdf

IOB. (2008) Impact evaluation: Primary education in Uganda. April 2008, ISBN 978-90-5328-361-5. Available at: www.government.nl/documents/reports/2008/04/26/iob-impact-evaluation-primary-education-in-uganda

John Paul II Justice \& Peace Centre (2014) The state of universal primary education schools in north and northeastern Uganda. Available at: www.jp2jpc.org/downloads/UPE\%20Report.pdf

Kadir, A.N.J (2019) Good governance issues in education system and management of secondary schools in Kwara State, Nigeria. E-Journal of Education Policy. Available at: https://files.eric.ed.gov/fulltext/EJ1234494.pdf

Miiro, G., Rutakumwa, R., Nakiyingi-Miiro, J., Nakuya, K., Musoke, S., Namakula, J., Francis, S., Torondel, B., Gibson, L.J., Ross, D.A. and Weiss, H.A. (2018) Menstrual health \& school absenteeism among adolescent girls in Uganda: A feasibility study. BMC Women's Health 18, (4). https://doi.org/10.1186/s12905-017-0502-z

Ministry of Education and Sports. (MoES) (2016a) The education and sports sector annual performance report, financial year 2015/2016. Available at: www.education.go.ug/wp-content/uploads/ 2019/08/ ESSAPRFY-2015-16.pdf

Ministry of Education and Sports. (MoES) (2016b) National education accounts report Uganda. Available at: http://uis.unesco.org/sites/default/files/uganda_nea_report-2016-en.pdf

Ministry of Education and Sports. (MoES) (2017) Education and sports sector strategic plan 2017/18-2019/20. Available at: https://planipolis.iiep.unesco.org/sites/planipolis/files/ressources/uganda_education_sector_strategic_plan _2017-2018_2019_2020.pdf 
Ministry of Finance Planning and Economic Development. (MoFPED) (2016) Budget speech financial year 2016/17: Enhanced productivity for job creation. Kampala, Uganda: MoFPED.

Mwalimu. (2016) Poor quality teachers choking education. New Vision 20 July 2016, pp. 22 \& 27. Available at: www.newvision.co.ug/tag/mwalimu-pullout

Namara, R.B. and Kasaija, J. (2016) Teachers' protest movements and prospects for teachers improved welfare in Uganda. Journal of Education and Training Studies. 4 (5). Available at: https://eric.ed.gov/?id=EJ1094638

Nanyonga, B. and Nanziri, P. (2013) Citizens' voices UPE schools versus PLE performance in Bukedea district - Malera sub-county. Report to Community Development Resource Network. Kampala, Uganda.

National Planning Authority. (NPA) (2015) Pre-primary and primary education in Uganda: Access, cost, quality \& relevance. Available at: http://npa.go.ug/wp-content/uploads/2018/04/NPA-PEC-Paper-Pre-Primary-andPrimary-Education-in-Uganda.pdf

Ocan, B. (2017) Impact of community level engagement in primary education: A case study of Oyam District, Northern Uganda, Uganda, East Africa. MA thesis, SIT Graduate Institute, Washington, DC, USA. Available at: https://digitalcollections.sit.edu/cgi/viewcontent.cgi?article=4079\&context=capstones

Office of the Prime Minister (OPM) (2016) Draft report of the process evaluation report of Universal Primary Education Programme in Uganda. Kampala, Uganda.

Okurut-Ibore, C.M. (2015) The nexus between local needs and aspirations of Ugandans and global education goals: A case study. PhD thesis, North Dakota State University, USA.

Oluka, S. and Opolot-Okurut, C. (2008) Performance in primary education in the Teso region: An exploratory study. Available at: http://cees.mak.ac.ug/sites/default/files/TESO_REPORT.pdf

Oxfam and We-Care (2018) Final report of the gender roles and the care economy in Ugandan households: The case of Kaabong, Kabale and Kampala districts. Available at: https://oxfamilibrary.openrepository.com/bitstream/handle/10546/620532/rr-gender-roles-care-economyuganda-130818-en.pdf? sequence $=4 \&$ isAllowed $=\mathrm{y}$

Prinsen, G. and Titeca, K. (2008) Uganda's decentralised primary education: Musical chairs and inverted elite capture in school. Public Administration and Development, 28, 149-164. https://doi.org/10.1002/pad.487

Reinikka, R. and Svensson, J. (2004) Local capture: Evidence from a central government transfer program in Uganda. The Quarterly Journal of Economics, 119 (2), 679-705. https://doi.org/10.1162/0033553041382120

The Global Economy.com (2020) Uganda: Student teacher ratio, primary school. Available at: www.theglobaleconomy.com/Uganda/Student_teacher_ratio_primary_school

Tromp, R.E. and Datzberger, S. (2019) Global education policies versus local realities. Insights from Uganda and Mexico. Compare: A Journal of Comparative and International Education. https://doi.org/10.1080/03057925.2019.1616163

Uganda Bureau of Statistics. (2017) Education as a means for population transformation. Thematic series based on the National Population and Housing Census 2014. Kampala Uganda. Available at: www.ubos.org/wpcontent/uploads/publications/03_2018Education_Monograph_Report_Final_08-12-2017.pdf

UNESCO. (n.d.) Gross enrolment ratio. Available at: http://uis.unesco.org/en/glossary-term/gross-enrolment-ratio

UNICEF. (2020) Quality of basic education. Available at: www.unicef.org/uganda/what-we-do/quality-education

Uwezo. (2019) Are our children learning? UWEZO Uganda eighth learning assessment report 2019. Kampala. Twaweza East Africa. Available at: https://twaweza.org/go/uwezo-uganda-eighth-learning-assessment-report

World Bank. (2010) Demand for good governance in the World Bank: Conceptual evolution, frameworks and activities. A background paper for Social Development Strategy Midcycle Implementation Progress report (MCIPR) Available at: www.academia.edu/40256702/Demand_for_Good_Governance_in_the_World_Bank_Conceptual_Evolutio n_Frameworks_and_Activities_Social_Development_Department_Demand_for_Good_Governance_Team

World Bank. (2012a) Poverty trends in Uganda: Who gained and who was left behind? Washington, DC. Available at: https://openknowledge.worldbank.org/bitstream/handle/10986/26712/695190WP0ugand00604020120Box36927 8B.pdf? sequence $=1 \&$ is Allowed $=\mathrm{y}$ 
World Bank. (2012b) Better governance improving education outcomes through better governance in Cameroon: Integrating supply and demand-side approaches. Available at: www.worldbank.org/en/news/feature/2012/04/11/better-governance-improving-education-outcomesthrough-better-governance-in-cameroon-integrating-supply-and-demand-side-approaches

World Bank. (2017) What do teachers know and do? Does it matter? Evidence from primary schools in Africa. Policy Research Working Paper 7956. Available at: https://papers.ssrn.com/sol3/papers.cfm?abstract_id=2906568

Yiga, D. and Wandega, A. (2010) Primary schools in Iganga district of Uganda. A study conducted by African Network for the Prevention and Protection against Child Abuse and Neglect (ANPPCAN). Available at: http://righteouspictures.com/wp-

content/uploads/2012/06/ANPPCAN_Uganda_report_teacher_absenteeism_2.pdf 